\title{
Do English Teaching Materials Foster Foreign Language Education Affectively?
}

\author{
${ }^{1}$ Istinye University, Istanbul, Turkey \\ Correspondence: Ali Işık, Istinye University, Istanbul, Turkey. E-mail: isikal@hotmail.com
}

$\begin{array}{ll}\text { Received: October 20, } 2017 & \text { Accepted: November 10, } 2017 \quad \text { Online Published: December 20, } 2017 \\ \text { doi:10.5539/jel.v7n1p272 } & \text { URL: https://doi.org/10.5539/jel.v7n1p272 }\end{array}$

\begin{abstract}
The paper investigates the role of English language teaching materials in the creation of a classroom atmosphere conducive to foreign language education. In this study, teachers and students were given a questionnaire and later interviewed to elicit their ideas about the materials. The data was analyzed and the responses of teachers and students were compared by using one-way ANOVA, post-hoc Scheffe test, and t-test statistics. The results indicated that, except for the regular state high school teachers and students, both teachers and students had serious problems with the ELT materials prepared by international publishers.
\end{abstract}

Keywords: materials evaluation, materials development, motivation, affective factors, commercial ELT materials

\section{Introduction}

Affective factors determine the learner involvement in the teaching/learning process, and consequently the rate and level of L2 proficiency (Brown, 2007; Ellis, 2008, 2015; Krashen, 2009, 2015). Many factors may serve to create an optimal affective environment for language learning and English language teaching (ELT) materials stand out as one of the most important ones.

First of all, the degree to which ELT materials are compatible with the needs of learners determines how efficiently the materials help learners realize their L2 learning goals (Garton \& Graves, 2014; McGrath, 2006; Tomlinson \& Masahura, 2017). The use of relevant texts and tasks in the classroom are more likely to motivate learners and help them get both cognitively and affectively involved in what they are studying (Hart 2003; Long, 2015; McDonough et al., 2013; Yuen, 2011). Hence, a detailed analysis of the learners' needs and selecting ELT materials accordingly foster both cognitive and affective involvement of learners (Kaewpet, 2009).

Another issue that needs to be taken into consideration is the relationship between ELT materials and English teachers' attitudes and classroom performance (Allen, 2015; McGrath, 2006). English teachers have their own personal beliefs about what kinds of ELT materials are fruitful to carry out language teaching/learning activities (Garton \& Raves, 2014). Thus, the degree to which ELT materials fit teachers' frames of reference, determines the degree to which English teachers develop positive attitudes towards those materials and use them fruitfully in their classrooms (Grossman \& Thompson, 2008; Tomlinson 2003, 2013).

To sum up, ELT materials, which are closely associated with EFL teachers' and learners' attitudes to the language learning process, are likely to affect their affective and cognitive involvement in the process and in turn the success level in EFL (Allehyani et al., 2017; Isik, 2014; McGrath, 2006). To the knowledge of the researcher, there has been no study in Turkey focusing on the relationship between ELT materials and affective factors. Hence it is essential to study the relationship between ELT materials and affective factors. So, the purpose of this study is to find answers to the following research questions:

1) How do EFL teachers consider the role of ELT materials in terms of influencing language education affectively?

2) How do EFL learners consider the role of ELT materials in terms of influencing language education affectively? 


\section{Method}

In this study, the EFL teachers and learners from secondary schools were asked to answer a questionnaire to get information about how they felt about the ELT materials they were using while teaching/learning English. The same items on the questionnaire were also addressed to the interviewees to explore their ideas in greater depth.

\subsection{Sample}

For this study 27 high schools in Turkey were visited. Nine of these schools were private high schools and 18 of them were state high schools. Ten of the state schools were state Anatolian high schools. Anatolian high schools and private high schools specify at least nine hours of EFL instruction per week in the ninth grade, with four hours per week in the tenth, eleventh, and twelfth grades. The third group in this study was general state high schools. Regular high schools have only four hours of EFL instruction per week. A total of 144 teachers and 811 students from 27 institutions participated in this study. Table 1 presents the total number of schools, teachers and students.

Table 1. Distribution of school types and participants

\begin{tabular}{llll}
\hline & Number of schools & Number of EFL teachers & Number of EFL learners \\
\hline Private high schools & 9 & 58 & 254 \\
State Anatolian high schools & 10 & 51 & 276 \\
General state high schools & 8 & 35 & 281 \\
\hline
\end{tabular}

In private high schools and state Anatolian high schools, generally available, commercial EFL materials prepared by international publishers are used. On the other hand, ELT materials used in general state high schools are locally produced.

\subsection{Research Instrument}

The measurement instrument used in this study is a $37-i$ tem questionnaire that was developed to evaluate the perceptions of individuals regarding English language teaching materials. The statistical analysis showed that the questionnaire has high reliability (Cronbach's alpha: 0.91) and validity (Cronbach's alpha: 0.93).

\subsection{Procedure}

The questionnaire was administered approximately two months after the lessons had begun. It was assumed that within that two-month period, both learners and teachers would have had enough experience with the materials and have already developed attitudes and ideas about the ELT materials they were using. To gather more detailed findings, a month later, retrospective accounts were gathered from both parties as suggested by Dörnyei (2007). At this point, the very same questions were asked to the participants to take a deeper look at their views. Since the same items on the questionnaire were used in the interview, it gave the participants the opportunity to verify and triangulate questionnaire results to help interviewees clarify their ideas.

\subsection{Data Analyses}

SPSS was used to analyze the data obtained in this study. The percentages related with the questionnaires and interviews were obtained by using descriptive statistics. A one-way ANOVA test was used to compare the data elicited from the teachers and students from the three different schools. For multiple comparisons, a post-hoc Scheffe test was used. A T-test was used to compare the questionnaire and interview results of teachers and students in the same schools.

\section{Results}

The comparative results of the EFL teacher and student questionnaires and interviews are given in Table 2. The results indicate that the groups varied in terms of their responses to the items in the questionnaire. To see if these differences are significant, the responses of teachers and students from three different types of schools were compared separately. The results are presented under the following titles below: 
Table 2. Teacher/student questionnaire/interview results

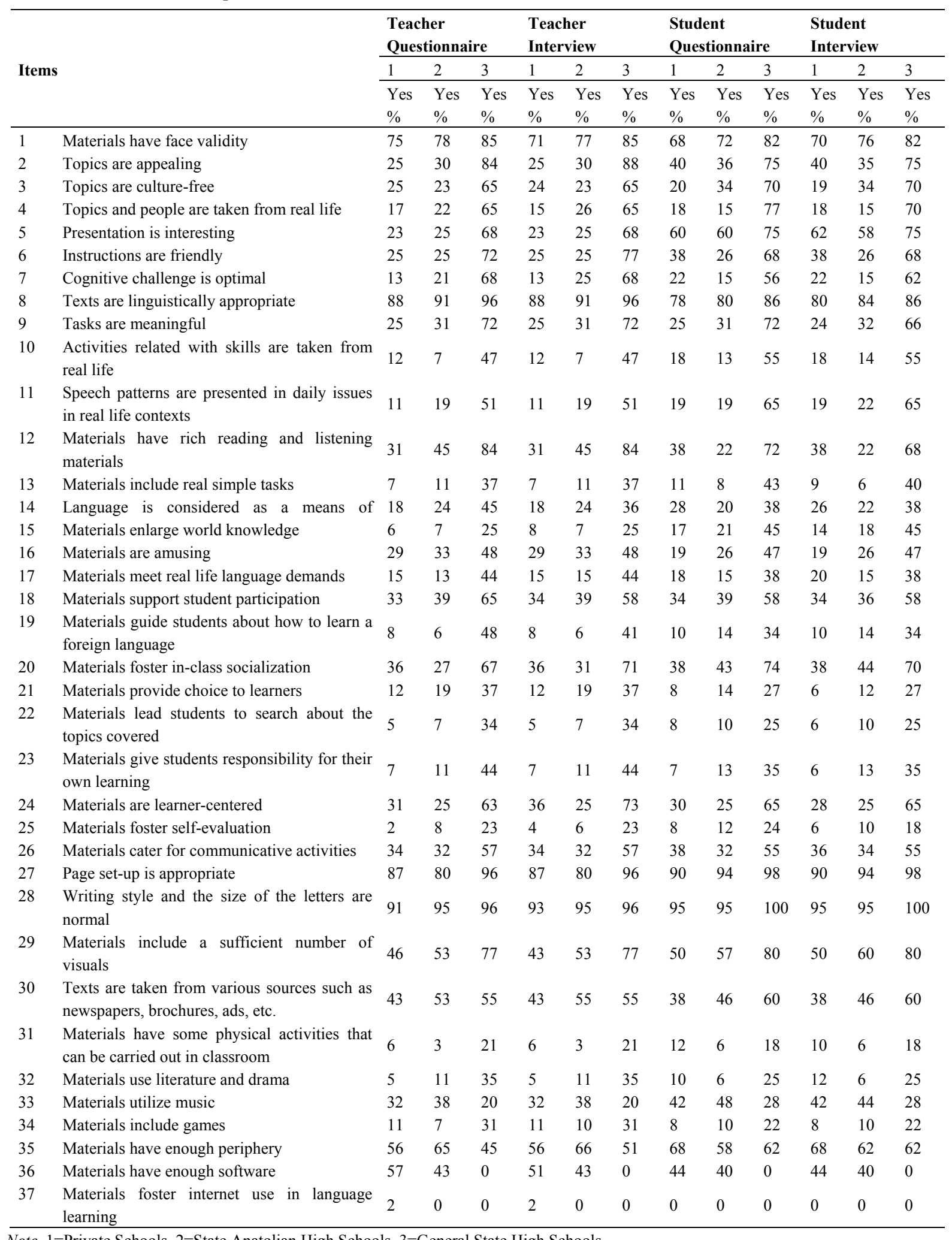

Note. $1=$ Private Schools, $2=$ State Anatolian High Schools, $3=$ General State High Schools.

\subsection{Findings of Teacher-Student Questionnaires}

Table 3 summarizes the comparison of data provided by the teachers working in private high schools, state Anatolian high schools and general state high schools. It indicates that there are significant differences among the teacher groups. In other words, the school type does affect the responses provided by the teachers. 
Table 4 presents the data obtained from the students studying in private high schools, state Anatolian high schools and general state high schools. It also indicates that the responses given to the questionnaire differ significantly. Hence, to analyze the data provided by the participants in detail, multiple comparisons were carried out for the teachers and students.

Table 3. Comparison of teacher responses

\begin{tabular}{llllll}
\hline & Sum of Squares & df & Mean Square & F & $\mathrm{p}$ \\
\hline Between Groups & 14098,865 & 2 & 7049,432 & 11,399 &, 000 \\
Within Groups & 66788,432 & 108 & 618,411 & & \\
Total & 80887,297 & 110 & & & \\
\hline
\end{tabular}

Table 4. Comparison of student responses

\begin{tabular}{llllll}
\hline & Sum of Squares & df & Mean Square & F & p \\
\hline Between Groups & 10934,072 & 2 & 5467,036 & 8,945 &, 000 \\
Within Groups & 66005,297 & 108 & 611,160 & & \\
Total & 76939,369 & 110 & & & \\
\hline
\end{tabular}

For detailed analysis, the teachers and students from private high schools were named as Group 1, those from state Anatolian high schools as Group 2, and the ones from general state high schools as Group 3. The data indicated that there are differences among these three different groups. Table 5 shows that the responses given by the teachers from private and Anatolian high schools tend to be similar but those of the teachers working in general state high schools were different from the two other groups of teachers.

Table 5. Multiple comparison of teacher groups

\begin{tabular}{lllll}
\hline (I) Group & (J) Group & Mean Difference (I-J) & Std.Error & Sig. \\
\hline 1 & 2 & $-2,11$ & & 0,936 \\
& 3 & $-24,89^{*}$ & & 0,000 \\
2 & 1 & 2,11 & \multirow{2}{*}{5,78} & 0,936 \\
& 3 & $-22,78^{*}$ & & 0,000 \\
3 & 1 & $24,89^{*}$ & & 0,000 \\
& 2 & $22,78^{*}$ & & 0,001 \\
\hline
\end{tabular}

Note. $*$ The mean difference is significant at the .05 level.

Table 6 presents the same comparison for the students in different schools. The results were similar to the comparison made with teachers. The responses given by the students from private and Anatolian high schools tend to be similar. On the other hand, those of the students in general state high schools are different from the two other groups of students.

Table 6. Multiple comparison of student groups

\begin{tabular}{lllll}
\hline (I) Group & (J) Group & Mean Difference (I-J) & Std.Error & Sig. \\
\hline 1 & 2 & 0,00 & & 1,000 \\
& 3 & $-21,05^{*}$ & & 0,002 \\
2 & 1 & 0,00 & 5,75 & 1,000 \\
& 3 & $-21,05^{*}$ & & 0,002 \\
3 & 1 & $21,05^{*}$ & & 0,002 \\
& 2 & $21,05^{*}$ & & 0,002 \\
\hline
\end{tabular}

Note. $*$ The mean difference is significant at the .05 level.

In order to get a detailed comparison of the data elicited both from the teachers and students in the same type of schools, t-tests were conducted. Table 7 indicates that there are no significant differences between the responses given to the questionnaire by the teachers and students in private high schools. 
Table 7. Comparison of teacher-student responses in private high schools

\begin{tabular}{lllllll}
\hline Groups & $\mathrm{N}$ & Mean & Std.Deviation & df & $\mathrm{t}$ & $\mathrm{p}$ \\
\hline Teacher & 37 & 28,35 & 24,73 & 72 & 0,60 & 0,550 \\
Student & 37 & 31,76 & 24,07 & & & \\
\hline
\end{tabular}

Table 8 indicates that there are no significant differences between the responses given to the questionnaire by the teachers and students in state Anatolian high schools.

Table 8. The comparison of teacher-student responses in state Anatolian high schools

\begin{tabular}{lllllll}
\hline Groups & $\mathrm{N}$ & Mean & Std.Deviation & $\mathrm{df}$ & $\mathrm{t}$ & $\mathrm{p}$ \\
\hline Teacher & 37 & 30,46 & 24,89 & 72 & 0,23 & 0,822 \\
Student & 37 & 31,76 & 24,56 & & & \\
\hline
\end{tabular}

Table 9 shows that there are no significant differences between the responses given to the questionnaire by the teachers and students in general state high schools.

Table 9. Comparison of teacher-student responses in general state high schools

\begin{tabular}{lllllll}
\hline Groups & N & Mean & Std.Deviation & df & t & p \\
\hline Teacher & 37 & 53,24 & 24,98 & 72 & 0,07 & 0,941 \\
Student & 37 & 52,81 & 25,51 & & & \\
\hline
\end{tabular}

\subsection{Findings of Teacher-Student Interviews}

A month after the questionnaire was completed, an interview was carried out to see whether both learners and teachers still had the same opinions and attitudes about the materials. When Table 10 and Table 11 are examined, the significant differences among the teachers' and students' responses elicited through the interviews can be observed.

Table 10. Comparison of teacher responses

\begin{tabular}{llllll}
\hline & Sum of Squares & df & Mean Square & F & p \\
\hline Between Groups & 14133,207 & 2 & 7066,604 & 11,371 & 0,000 \\
Within Groups & 67116,486 & 1008 & 621,449 & & \\
Total & 81249,694 & 110 & & & \\
\hline
\end{tabular}

Table 11. Comparison of student responses

\begin{tabular}{llllll}
\hline & Sum of Squares & df & Mean Square & F & p \\
\hline Between Groups & 10356,883 & 2 & 5178,441 & 8,250 & 0,000 \\
Within Groups & 67790,865 & 108 & 627,693 & & \\
Total & 78147,748 & 110 & & & \\
\hline
\end{tabular}

To analyze the interview data provided by the teachers and students, again the teachers and students from private high schools were named as Group 1, those from Anatolian high schools as Group 2, and the ones from general state high schools as Group 3. Similar to the data obtained from the questionnaire, the interview data indicated that the teachers working in general state high schools account for the difference between teachers working in the three different types of schools. The responses given by the teachers from private and Anatolian high schools tended to be similar. On the other hand, those of the teachers working in general state high schools were different from the two other groups of teachers. Table 12 summarizes the multiple comparisons of teacher responses. The results obtained about student groups are similar to those of teachers. The responses given by the students from private and Anatolian high schools were similar. On the other hand, those of the students in general state high schools were different from the two other groups of students. Table 13 presents the multiple comparisons of student responses. 
Table 12. Multiple comparison of teacher groups

\begin{tabular}{lllll}
\hline & & $\begin{array}{l}\text { Mean } \\
\text { Difference }\end{array}$ & Std.Error & Sig. \\
\hline 1 & (I) Group & (J) Group & $-2,68$ & \\
& 2 & $-25,16^{*}$ & & 0,899 \\
2 & 3 & 2,68 & 5,80 & 0,000 \\
& 1 & $-22,49^{*}$ & & 0,899 \\
3 & 3 & $25,16^{*}$ & & 0,000 \\
& 1 & $22,49^{*}$ & & 0,000 \\
\hline
\end{tabular}

Note. ${ }^{*}$ The mean difference is significant at the .05 level.

Table 13. Multiple comparison of student groups

\begin{tabular}{lllll}
\hline (I) Group & (J) Group & Mean Difference (I-J) & Std.Error & Sig. \\
\hline 1 & 2 & $-0,49$ & & 0,997 \\
& 3 & $-20,73^{*}$ & & 0,003 \\
2 & 1 & 0,49 & 5,82 & 0,997 \\
& 3 & $20,24^{*}$ & & 0,003 \\
3 & 1 & $20,73^{*}$ & & 0,003 \\
& 2 & $20,24^{*}$ & 0,003 \\
\hline
\end{tabular}

Note. ${ }^{*}$ The mean difference is significant at the .05 level.

To see how the teachers and students in the same type of schools answered the interview questions, the responses of the teachers and students were compared. Table 14 indicates that there are no significant differences between the responses given during interviews by the teachers and students in private high schools.

Table 14. Comparison of teacher-student responses in private high schools

\begin{tabular}{lllllll}
\hline Groups & $\mathrm{N}$ & Mean & Std.Deviation & df & $\mathrm{t}$ & $\mathrm{p}$ \\
\hline Teacher & 37 & 28,24 & 24,40 & 72 & 0,56 & 0,578 \\
Student & 37 & 31,43 & 24,63 & & & \\
\hline
\end{tabular}

Table 15 indicates that there are no significant differences between the responses given during the interviews by the teachers and students in state Anatolian high schools.

Table 15. Comparison of teacher-student responses in state Anatolian high schools

\begin{tabular}{lllllll}
\hline Groups & $\mathrm{N}$ & Mean & Std.Deviation & $\mathrm{df}$ & $\mathrm{t}$ & $\mathrm{p}$ \\
\hline Teacher & 37 & 30,92 & 24,80 & 72 & 0,17 & 0,864 \\
Student & 37 & 31,92 & 25,16 & & & \\
\hline
\end{tabular}

Table 16 shows that there are no significant differences between the responses given during the interviews by the teachers and students in general state high schools.

Table 16. Comparison of teacher-student responses in general state high schools

\begin{tabular}{lllllll}
\hline Groups & $\mathrm{N}$ & Mean & Std.Deviation & df & $\mathrm{t}$ & $\mathrm{p}$ \\
\hline Teacher & 37 & 53,41 & 25,57 & 72 & 0,21 & 0,834 \\
Student & 37 & 52,16 & 25,36 & & & \\
\hline
\end{tabular}

\section{Discussion}

On the whole, the responses given to the items on the questionnaire/interview can be put into three different categories. The first category includes the positive response by all schools to items 1, 18, 27, 28, 29 in the questionnaire (refer to Table 2). All the participants seem to have no problems with items 30 and 35 . The second category included the overall negative response to items $10,13,14,15,16,17,19,21,22,23,25,31,32,33,34$, 
36, 37. Finally, the last category indicated the difference between general state high schools and the other two groups. The participants in private high schools and Anatolian high schools were negative about items 2, 3, 4, 5, $6,7,9,12,18,20,24,26$, while those in general state high schools were positive.

When the responses of the teachers and students in the same type of schools are compared, it can be concluded that the teachers and students in the same type of schools tend to give similar responses (refer to Table 13). In private high schools, teachers and students gave considerably different responses to the items $2,5,6,15$, 35. In Anatolian high schools, they offered slightly different opinions about items 3, 5, 12, 15, 27, and in general state high schools, items $4,11,15,35$ got noticeably dissimilar responses from the teachers and students. For item 15 , there is a difference between teacher and student responses in all type of schools. Hence, the data reveals that not the role of the participants (teacher or student) but the school type is an effective factor with respect to the opinions of participants about the ELT materials.

The results can also be discussed in two ways: private school and state Anatolian high school teachers and students on one hand and regular state high school teachers and students on the other hand. The information provided by the private school and state Anatolian high school teachers and students is similar. There could be several reasons for this: First of all, private high schools and state Anatolian high schools have more English instruction per week than general state high schools. Moreover, private high schools and state Anatolian high schools use commercial ELT materials prepared by international publishers. Regular schools use the ELT materials produced by the Turkish Ministry of Education and local publishers. Consequently, because of the similarities in the syllabi and the materials used, private high schools and state Anatolian high schools have similar backgrounds and foreign language education experiences. Hence it is not surprising then that the information provided by them is also similar.

Some of the findings can be evaluated in detail as follows: The majority of the private and state Anatolian high school teachers are dissatisfied with the choice of the topics in ELT materials. Moreover, some of the topics are found to be culture-specific and include artificial people, situations, and events. Moreover, three-fourths of the teachers stated that direct or indirect focus on language forms makes ELT materials artificial and boring with no practical use. Similarly, three-fourths of the teachers mentioned that there is no real focus on the integrated skills and skills have a subservient role to present and practice target language forms. On the contrary, the regular state teachers are positive about ELT materials. The majority are happy with the choice of the topics. They mentioned that learners learn new linguistic items easily and use them for communicative purposes.

The results obtained from the private and state Anatolian high school students are also quite similar. About two-thirds of the students indicated that the topics in ELT materials are boring and culture-specific. They reported that ELT materials are artificially designed to teach forms with no or weak emphasis on the real-life use of language. Language skills are not handled in their own right and the integrated-skills approach is neglected. On the other hand, they seem to be satisfied with the page layout and the way activities are presented. On the other hand, the students from the general state high schools are positive, like their teachers, about ELT materials which are published in Turkey. Three-fourths of the students found the topics interesting and stated that ELT materials help them learn grammar and vocabulary items and improve their skills.

To sum up, the data suggests that ELT materials used in both private high schools and state Anatolian high schools are unlikely to create an affectively optimal environment for English language education. On the other hand, in general state high schools both ELT teachers and students have positive attitudes toward ELT materials.

\section{Conclusion}

The study revealed that both the teachers and students have serious problems with the ELT materials prepared by international publishers. First of all, in order to improve the problem, teachers should be empowered and equipped with theoretical knowledge and practical skills to develop and adapt the ELT materials appropriate for their students (Garton \& Graves, 2014; Kumaravadivelu, 2016; Tomlinson, 2003). Furthermore, since each context is unique and teachers are the ones who know the needs, interests, and expectations of the students and the context of language teaching, they can adapt/design the most suitable ELT materials and contribute to create an optimal environment for language learning (Bax, 2003; Harwood, 2014; McGrath, 2002). Secondly, material developers should collaborate with teachers or include them in the materials development team when developing materials to come up with handy and relevant ideas and materials in language education (Richards, 2006). Thirdly, learners should be included in the materials preparation process (McGrath, 2006). When learners participate in the materials evaluation/development process, they are likely to contribute to the language learning process more (Yuen, 2011). Fourthly, materials development/adaptation should be based on needs and context analysis (Graves, 2000; Kaewpet, 2009). The information obtained from these analyses should form the base on 
which the materials are written or adapted (Richards, 2006). Consequently, providing learners with hands-on, relevant materials which have direct use in real life facilitates both cognitive and affective involvement of learners in language learning (Long, 2015). Finally, EFL materials should be piloted and studied in the classroom to see how they work and to what extent they serve to fulfill needs and interests of the students (Barrios \& de Debat, 2006; Tomlinson, 2003). As a result, with the use of the most appropriate ELT materials, optimal affective context for language learning can be created in language classes.

\section{References}

Allehyani, B., Burnapp, D., \& Wilson, J. (2017). A comparison of teaching materials (school textbooks vs authentic materials) from the perspective of English teachers and educational supervisors in Saudi Arabia. International Journal of English Language and Linguistics Research, 5(2), 1-14.

Allen, C. (2015). Marriages of convenience? Teachers and coursebooks in the digital age. ELT Journal, 69(3), 249-263. https://doi.org/10.1093/elt/ccv005

Barrios, M. L., \& de Debat, V. (2006). Minding the needs of the Argentine learner: Global textbooks and their adapted version for the local context. Folio, 10(2), 14-16.

Bax, S (2003). The end of CLT: a context approach to language teaching. ELT Journal, 57(3), 278-287. https://doi.org/10.1093/elt/57.3.278

Brown, H. D. (2007). Principles of language teaching and learning. White Plains, NY: Pearson\&Longman.

Dörnyei, Z. (2007). Research methods in applied linguistics: Quantitative, qualitative, and mixed methodologies. Oxford: Oxford University Press.

Ellis, R. (2008). Principles of instructed second language acquisition. CAL December. Retrieved from http://www.cal.org/resources/digest/digest_pdfs/Instructed2ndLangFinalWeb.pdf

Ellis, R. (2015). Understanding second language acquisition. Oxford: Oxford University Press.

Garton, S., \& Graves, K. (Eds.). (2014). International perspectives on materials in ELT. Basingstoke: Palgrave Macmillan. https://doi.org/10.1057/9781137023315

Graves, K. (2000). Designing language courses. Cambridge: Cambridge University Press.

Grossman, P., \& Thompson, C. (2008). Learning from curriculum materials: Scaffolds for new teachers?. Teaching and Teacher Education, 2, 2014-2026. https://doi.org/10.1016/j.tate.2008.05.002

Hart, I. (2003). The outsider's gaze: A learner-centered aproach to language-teaching materials, Educational Media International, 40(3/4), 287-292. https://doi.org/10.1080/0952398032000113202

Harwood, N. (Ed.). (2014). English language teaching textbooks: Content, consumption, production. Basingstoke: Palgrave Macmillan. https://doi.org/10.1057/9781137276285

Isik, A. (2014). A test of the effect of interesting and relevant subject matter on second language acquisition. The International Journal of Foreign Language Teaching, 10(1), 20-23.

Kaewpet, C. (2009). A framework for investigating learner needs: needs analysis extended to curriculum development. Electronic Journal of Foreign Language Teaching, 6(2), 209-220.

Krashen, S. (2009). Principles and Practice in Second Language Acquisition. Retrieved from $\mathrm{http} / / / \mathrm{www}$. sdkrashen.com/Principles_and_Practice/index.html

Krashen, S. (2015). The ecstacy hypothesis. Perspectives, 14, 7-9. (Kanda University of International Studies).

Kumaravadivelu, B. (2016). The decolonial option in English teaching: Can the subaltern act? TESOL Quarterly, 50(1), 66-85. https://doi.org/10.1002/tesq.202

Long, M. (2015). Second language acquisition and task-based language teaching. Malden, MA: Wiley Blackwell.

McDonough, J., \& Shaw, C. (2003). Materials and methods in ELT. Oxford: Blackwell Publishing.

McDonough, J., Shaw, C., \& Masuhara, H. (2013). Materials and methods in ELT: A teacher's guide (3rd edition). London: Blackwell.

McGrath, I. (2002). Materials evaluation and design for language teaching. Edinburgh: Edinburgh University Press. 
McGrath, I. (2006). Teachers' and learners' images for coursebooks. ELT Journal, 60(2), 171-180. https://doi.org/10.1093/elt/cci104

Richards, J. C. (2006). Materials development and research-making the connection. RELC, 37(1), 5-26. https://doi.org/10.1177/0033688206063470

Tomlinson, B. (2003). Developing materials for language learning. London: Continuum.

Tomlinson, B. (Ed.) (2013). Developing materials for language teaching (2nd edition). London: Continuum Press.

Tomlinson, B., \& Masuhara, H. (2017). A complete guide to the theory and practice of materials development for language learning. Chichester: Wiley Blackwell.

Yuen, K. (2011). The representation of foreign cultures in English textbooks. ELT Journal, 65(4), 458-466. https://doi.org/10.1093/elt/ccq089

\section{Copyrights}

Copyright for this article is retained by the author(s), with first publication rights granted to the journal.

This is an open-access article distributed under the terms and conditions of the Creative Commons Attribution license (http://creativecommons.org/licenses/by/4.0/). 